\title{
Would Digitalization Project Impact Corporate Resilience? An Evaluation of the Nigeria Deposit Money Bank (DMB)
}

\author{
Deebii Nwiado $^{1} \quad$ Leene Lezarsi Torbira $^{2} \quad \mathrm{PhD}$; Onu, Kinsley Ezebunwa ${ }^{3}$ \\ 1.Department of Economics, Faculty of Social Sciences, Ignatius Ajuru University of Education, Port Harcourt, \\ Nigeria \\ 2.Department of finance and banking, university of Choba - Port Harcourt Nigeria \\ 3.Department of Economics, Faculty of Social Sciences, Ignatius Ajuru University of Education, Port Harcourt, \\ Nigeria \\ Corresponding author: *Deebii Nwiado PhD, Department of Economics, Faculty of Social Sciences, Ignatius \\ Ajuru University of Education, PMB 5047, Port Harcourt, Nigeria.
}

\begin{abstract}
This paper examined whether digitalization of key functional units, product and service offerings by Nigeria deposit money banks (DMB) could stymie the steaming competition from Fintech startup firms. Four key bank performance indexes (KPI): - customer deposit, loan \& advances to customer, asset under management and operational expense were isolated. Eight Nigeria deposit money banks (DMB) were randomly selected and designated either as, "highly or "less digitalized". The four selected bank key performance index (KPI), were tested, using rate (\%) of change on a pair of a "highly and a less digitalized" bank. The highly digitalized bank proxied Fintech startup firms while the less digitalized are the normal banking firms. The results produced significant difference in favour of the less digitalized normal banks. In all the cases statistically analyzed, the less digitalized banks out performed, in all four key bank KPI, the highly digitalized Fintech startup firms. Our findings denied the much-orchestrated Fintech startup firms outperforming ordinary banks in the financial services market. Conclusively - excessive technological deployment adds tittle or nothing to banks' performance: revenue generations, competitive stamina and even resilience. Agbaje of Guaranty trust bank (G. T Bank) was right; “.... dominating the market is beyond just acquiring the best of technology." Fintech startup firms are no threat to the brick-and-mortar model.
\end{abstract}

Keywords: Fintech, digitalization, customer deposits, asset, loan \& advances, ecosystem.

DOI: $10.7176 / \mathrm{EJBM} / 13-24-06$

Publication date: December $31^{\text {st }} 2021$

\section{Overview and Introduction}

This paper examined the recent surge in digital transformation projects embarked upon by corporate organisations across board. Our focused though is on the digitalization projects in the banking industry. The history of bank digitalization in Nigeria dates back a few decades to 1989 when the first Automated Teller Machine (ATM) was installed by the National Cash Registry (NCR) for the now defunct Societe Generale Bank of Nigeria (SGBN) https://www.studymode.com/essays/An-Assessment-Of-The-Use-Of-534707.html. Thereafter, digitalization of banking functions, consumer products and service offerings, went up fairly rapidly and have since then being the main tool of competition, not only heightening industry entry barriers, but also making banking service and product offerings cost effective. By the end of the last few decades, a number of banks in the industry, especially Nigeria deposit money banks (DMB), have digitalized most, if not all of its operations to ward off obsolesce and survive the intense competition driven by startup Fintech firms.

Recent digitalization projects in Nigeria deposit money banks, unlike in the past are driven by the dread of Fintech startup firms entry into the retailed financial services market, formerly an exclusive preserve of banks. Fintech firms are structurally lean, agile, innovative and are at the cutting edge of technology which they easily deploy to forestall competition. These features enabled Fintech startups to disrupt the conventional banking model that are naturally broad and in some case slow, at adopting technology. Unlike banks, Fintech easily leverages technology in its product and service offerings in the retailed financial market, insurance etc.

Even as startups, Fintech firms are lean and cost effective, able to deliver tailored financial services to consumers at comparably low cost. In reaction to the threats posed by Fintech firms to its core products and service markets, mortar and brick banks have resorted to massive digitalization, especially in the personal, retailed banking services and products, where Fintech startups competitive threats are intensive and fast moving. Are Nigeria deposit money banks (DMB) sufficiently cushioned by current digitalization projects? Will it provide the needed succor for Nigeria banks to remain afloat, stay competitive and be resilient to macroeconomic disturbances, a sure feature of the financial services market?

\subsection{Background}

The Nigerian banking industry that depends largely on earnings from retailed banking for over 80 percent of its 
annual revenue and survival, appears to be drowning under the intense competitive heat generated by Fintech firms. Price Water Copper ( $\mathrm{PwC}$ ) in a recent (undated) report noted, "Africa is home to more than 400 Fintech firms. The continent's three key hubs are: - South Africa, Kenyan and Nigeria - accounting for a larger proportion of the Fintech firms." Thus, putting traditional banking model under steaming competition pressure.

Fig 1.1 Total investment activity (VC, PE and M\&A) in fintech
2013-2018

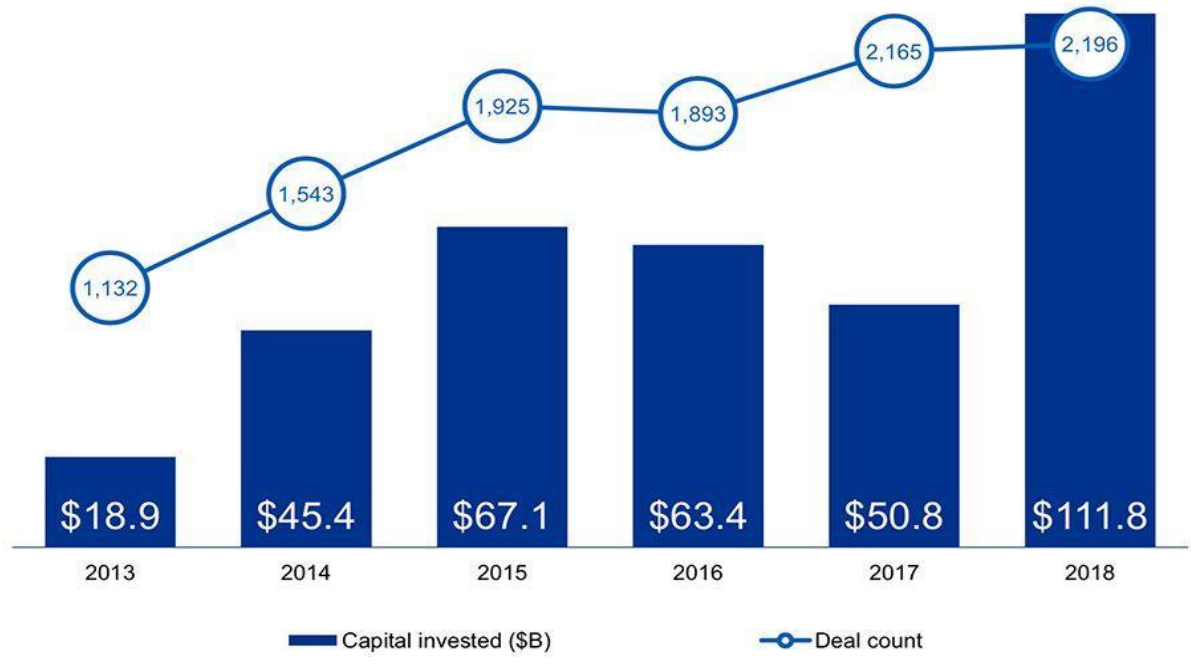

\section{Source: Consultancy.eu}

Fig.1.1 above presents the global growth in Fintech investments from 2013-2018 which appears to be increasing at geometric progressions. By 2020 global investments in Fintech reached $\$ 105.3$ billion across 2,876 deals. (Jennifer Samuel 2020). In Africa, Fintech investments amounted to a whopping over \$53-million in 25 in disclosed deals (Timm 2019).

Only when threats from sleek Fintech startups became so palpable in the immediate past decade of the $90 \mathrm{~s}$, did Nigerian deposit money banks (DMB), which appeared to have been completely oblivious of the astonishingly low entry barrier to the Nigeria retailed financial service markets woke up to the competitive threats posed by Fintech startups to its existence. Nigerian banks only lately came to the realization that the days when fixed assets (example branches) served as deterrent (entry barriers) into the financial markets were over. As the internet technology emerged in the 1980s, upstarts Fintech firms with lean cost structures, enabled by technology were capable of virtually running financial services online.

The popularity of Fintech startups in Africa, and it's phenomenal growth in countries (South Africa, Kenya and Nigeria) of sub-Sahara Africa is attributed to a number of key factors. Young and growing populations - the current demographic ecosystem of many African nations-Nigeria, Kenya and South Africa regarded as key hubs, support the growth of Fintech firms, due to their tendencies to consume the technology being launched in the markets. It is further argued that the wide-spread mobile phone access through smartphones on the continent estimated to reach 525 million by 2022, also drives the Fintech industry in sub-Sahara Africa countries.

Africa's poor financial inclusion provides another explanation amongst others for a thriving Fintech industry in sub-Sahara African market. The Low levels of financial inclusion in the formal banking systems in the entire continent drives the growth of Fintech, with companies incentivized to tackle this situation and offer solutions. Chris Steward, cited by Jonathan Gregson (2019), said of this: "The lower the level of financial inclusion in a country, the greater the opportunities for Fintech and consequently the more likely that the regulator will take a more tolerant view of the range of their activities." Diverse product offerings together with little financial inclusion in the formal banking system across the continent, make payment solution providers dominate the Fintech key hub markets of sub-Sharan Africa.

Faced with the intensed competition driven by Fintech startup firms, banks are advised to reduce cost-toincome ratio and not add on functions. In its most recent Global Banking Annual Review (December 2020), McKinsey \& Company recommended that banks should build what it calls "productivity engine": improve its capital management capabilities and re-build its risk-management muscles to stymie competition. From indications, Nigeria deposit money banks (DMB) may not sufficiently achieve cost savings enough to ward off the steaming competition from Fintech startup firms only in a massive one-off digital implementation programs. Rather, a mindset and capabilities - reset third party spending, move to minimum viable central functions and dedicated to continuous improvement aimed at greater productivity and better customer experience could generate the needed resilience for deposit money banks to stay competitive and afloat in the new hostile global financial market system. 


\subsection{Conceptualization and general discussion}

Though the concept "Fintech" is fairly ubiquitous in today's financial services industry literature, and could almost be taken for granted, we attempt to clarify what truly it conveys and its different applications. Kagan (2020), reviewed and updated by Estevez (August 2020), conceptualized Fintech as: "a new technology that seeks to improve and automate the delivery, and use of financial services." Though the name "Fintech" pointedly situates it to fit financial services and product offerings, applications of the new technology cuts across industries. Fintech assist business owners, consumers and managers to better manage their financial operations. "In other words, Fintech simply puts, promotes the use of digital technology to come up with innovative products such as mobile payments, alternative finance, online banking, big data and overall financial management." (ibid).

In a consultative document issued (2017), the Basel Committee on Banking Services (BCBS) adopted the Financial Stability Board's (FSB) working definition which conceptualized Fintech as: "technologically enabled financial innovations that could result in new business models, applications, processes, or products with an associated material effect on financial markets and institutions and the provision of financial services." Innovation appears to be the ubiquitous denominator in most of the definitions of Fintech because its' financial services delivery and products offering are by and large "innovative."

Consumer credits offered using Fintech technologies is less cumbersome, inexpensive and some cases initiated and concluded by the consumer. Example, cash credits offered by a number of Nigeria deposit money Banks (DMB). Besides, that Fintech firms could simultaneously operate in several financial markets: retail financial market, insurance, cryptocurrency, consumer banking, asset management and payment solution is innovative enough. More generally, Fintech encompasses any emerging technology that offers faster and more efficient means of delivering products and financial services that the traditional mortar and brick banks currently dominantly available in the financial market are unable to provide.

Fintech applications vary depending on specializations. Payment Gateways or platform are electronic payment systems which had been around before e-commerce was born. These online payment systems have revolutionized payment, making it convenient, easy, and highly accessible to all (financial inclusion). The most notable contribution of payment gateways is that they enable people to send money, circumventing the expensive service charges of the traditional mortar and brick model. By avoiding expensive bank charges, payment gateways afford consumers considerable leverage - cost savings from bank charges. Examples of payment gateways is:

PayPal - founded in 1998, is a major player in the online payment systems in particular, the electronic money transfers. PayPal has over 286 million active account holders. It is a U.S.-based payment gateway and operates in over 200 markets across the world and in over 100 currencies. Its total revenues for 2018 reached US\$15.45 billion. (https//financesonline.com/what-is-fintech).

Consumer Banking - this is another category of Fintech that has taken the world by storm in the consumer banking segment, in particular the retailed financial market. A typical consumer Fintech is a provider of alternative banking services. It offers banking products and services mostly to the several unbanked sub-Sahara Africans. Banks' exorbitant charges, make it unaffordable for the average persons to avail their services. The Fintech's alternative consumer banking product offerings are designed to address this long-standing issue. By making financial products and services accessible, Fintech firms provide affordable alternative for consumers.

Robo-Advising and Stock-Trading Apps have altered practices in the asset management sector. This innovative Fintech service uses smart algorithm technology to provide intuitive asset recommendations. In effect, Robo-Advising has reduced portfolio management troubles and achieved unprecedented efficiency, by lowering the costs of portfolio management. Financial advisers can now analyze numerous portfolio options more efficiently, $24 / 7$, simultaneously. No wonder, an increasing number of Robo-advising services continue to emerge in the industry.

Though Fintech is consistently generally conceived as an innovative modern technological outfit that is easily deployed in the financial services and product markets, its services vary amongst startups Fintech firms. The challenge though remains to assess its true impacts on competition in the financial services market place. Conventional banks are jittered by the surge in Fintech's financial service and product offerings in the different segments of financial services markets, which in the past were exclusively dominated by banks. This paper is intended to logically assess the different services and product offerings available through Fintech, and determine the level of resilience recent bank digitalization projects could offer banks in the competitive market place. We ask the question whether the surge in digital projects by banks will help put them at par with Fintech firms in smart product and services offerings.

"Corporate resilience" is conceptualized, in the context of this paper, to define the ability of a corporate organization (a bank) to stand competition in the market place and remain a going concern into the far undefined future.

The Nigeria banking industry has in the past few decades witnessed a number of turbulent industrial experiences. The bank consolidation exercised of 2004 triggered by the Central Bank of Nigeria (CBN) reduced 
the numerical strength of banks in the industry from some eighty banks to about twenty-five of today. Thereafter a number of other reforms have followed aimed at making Nigeria one of the World largest economics in which banks will play prominent roles. But the sudden appearance of lean cost-effective Fintech startup firms in the financial services market, a core banking terrain, beginning late 90s' generated a new competitive challenges or financial stress for Nigeria deposit money banks (DMB).

\subsection{Measuring bank resilience and competitiveness}

Measuring bank resilience and competitiveness, operating in the same market with lean cost-effective Fintech startups in the core financial service markets could pose some challenges. This we could achieve using bank key performance index (KPI) as; Customer deposit account size, loan and advances to customers etc. These are financial assets which could provide sufficient competitive edge for a bank. We will use them to measure a bank resilience (strength) in the market place. It is only banks with strong financial capabilities, that are able to stay and stand competition in the market place far into the unforeseeable future. Loan and advances to customers generate interest revenues that keeps a bank afloat. Granting loans and advances to customers are the core business functions of a bank and interest charges earned on these transactions provide the most significant sources of revenues for banks. Customer deposits provide banks almost a cost-free fund with which banks disbursed loans and advances to customers to earn interests.

Asset under management is an indicator of the size of a bank's wealth and speaks volume for the bank's financial strength. The larger the size of a bank's asset, the stronger the bank. Low banking expense compares it with Fintech startup, which are naturally lean and cost efficient structurally. By conjecture, we believe banks that are highly digitalized should have lean cost structure and be efficient to enjoy low operational expense, like Fintech firm. In this work, bank operational expense is defined by "personal expense" alone which excludes other operational expense. Other operational expense varies greatly in their contents and spread amongst banks; they therefore do not provide a consistent measure for the estimation of cost reduction probably enjoyed by a highly digitalized bank.

By conjecture banks that deploy technology through highly digitalized functional units and services offerings, should have large customer account volume (customer deposits) and should also be able to dispense loans and advances easily to customer via technology like their Fintech counterpart. We hypothesized; these banks should earn large interest spreads to remain resilience to competition. We use these bank key performance indicators (KPI) conceptually clarified here to access the ability of a bank to stay competitive and remain resilience in the financial service market place in the face Fintech competitive threats.

\subsection{Review of literature}

The term "Fintech" has exploded in popularity in recent years and is used variously to describe a wide array of innovations and actors in a rapidly evolving financial environment. Assessing the possible impacts of Fintech startups on banking core markets, Dietz, M. et.al (2016) noted, "Banking historically has been one of the business sectors most resistant to disruption by technology". These authors further asserted, "Banks have "special status" of being regulated institutions that supply credits, the lifeblood of economic growth, and have sovereign insurance for their liabilities (customer deposits). Consumers have generally been slow to change financial-services providers." In other words, Fintech, though common place and operating on several fronts, poses very little or no threats to core banking markets and the continuous existence of the banking industry. Bank as a financial institution remains uniquely and systematically important to society and the economy of all nations. Unlike startup Fintech firms, banks are in a highly regulated industry and offer insured security.

A report dated (2019) and titled: "Fintechs in Sub-Saharan Africa an overview of market developments and investment opportunities." co-authored by Hientz \& Bhatia elaborated a "Fintech ecosystem framework" in subSahara Africa. For a thriving Fintech landscape to evolve, Hientz \& Bhatia postulated, "there must be a local Fintech ecosystem in place." Like the Fintech sectors in more developed financial markets, the payment segment of Sub-Sahara Africa (SSA) Fintech is the most dominant. The large unbanked population and the correlating high demand for financial inclusion, together with a high concentration of mobile phones in the sub region, make the Fintech payments segment the most dominant in SSA Fintech landscape (ibid).

Hientz \& Bhatia (ibid) named the "four pillars" of a local enabling Fintech ecosystem as: Talent, Demand, Policy and capital. According to these authors, sub-Sahara Africa (SSA) boast of the most vibrant and fastest growing workforce globally, which is predicted to represent over $25 \%$ of the global workforce by 2050 . Yet in the face of this, only limited employment opportunities exist in the local market. The demand for Fintech products and service offerings is overwhelming in the key Fintech hub economies: South Africa, Nigeria and Kenya. This is due mainly to the fast growing and the large unbanked population in these countries. These together with an underdeveloped financial sector, which in some cases leave large chunks of economically viable markets (asset, portfolio management, mortgage, commodity etc.) barren, created the high demand for Fintech firms which now offer these services and product thus substituting banks services in these markets. 
Equally important is the policy landscape that exist for Fintech start-ups in the majority of SSA countries. Governments in SSA are starting to be supportive and interested in the development of Fintechs and their innovative capabilities. But the situation in Nigeria is slightly different. For example, the exclusion of Fintech from using BVN as an identification for prospective customers is a serious hindrance for Fintech growth and development. Yet Nigeria is one key Fintech hub in sub-Sahara Africa due to its large and ever-growing unbanked population albeit financial exclusion. "There are vast potentials for growth: Nigeria has the largest population in SSA (60\% unbanked), and the population of Lagos is expected to double in the next 15 years." (ibid).

Kola-Oyeneyin et al (2020), noted; "a youthful population, increasing smartphone penetration, and a focused regulatory drive to increase financial inclusion and cashless payments....." as the Fintech industry driver in Nigeria. Besides, the large unbanked Nigerians, (only $32 \%$ of Nigerian has debit card. United Nations Statistics Division (2017). The civil population continue to increase guaranteeing future prospects to the growth of Fintech firms in the sub-region.

Yermack (2018), in a (NBER WORKING PAPER SERIES No. 25007) discussed the emergence of Fintech in Kenya in sub-Sahara Africa, focusing on M-Pesa, a Fintech firm lunched in 2007 by Safaricom, an affiliate of Vodafone. Yermack asserted that, more rapid growth of Fintech in sub-Sahara Africa and most of the developing countries is impaired by the inadequacies of electrical and communications infrastructure. These countries, going by Yermack assertion, "have only limited, unreliable access to broadband Internet connections and smartphone handsets." Confirming this assertion, data from the www.internetworldstats.com; databank.worldbank.org; showed Nigeria, a key Fintech hub in SSA having only 61\% electrical penetration, 50\% internet penetration and $80 \%$ mobile phone penetration. These do not compare favourably with South Africa, another Fintech key hub with $65 \%$ electrical penetration, $85 \%$ internet penetration and $79 \%$ mobile phone penetration. (See Appendix A) for details penetration index for the rest of SSA countries.

Agoboola (2014), discussed the banking industry response to the threat posed by Fintech firms in the financial services industry. He noted that banks have evolved newer models such as internet banking, mobile banking and even new business units have emerged within the banking sector following the digitalization of banking functions and services all intended to face off competition from Fintech. Graham (2021), recommend banks to play "the Fintech game." "Fintech is assumed to be a modern movement, yet the use of technology to assist financial services offering is by no means a recent phenomenon. Financial services is an industry that introduced credit cards in the 1950s, internet banking in the 1990s and since the turn of the millennium, countless payment technology." Implying that, the banking industry was even in the market of offering financial services and products using technology long before the arrival of Fintech.

Still on the repose of banks to the presumed threats from Fintech in the financial service market, Agbaje, the Chief Executive Officer (CEO) of Guaranty Trust Bank (GT Bank) expressed no fears of Fintech: "The emergence of Fintech and Network providers in the banking sector doesn't frighten me despite their disruption of the banking industry." "I have no fear for Telcos; we are ready for Telcos. All we ask for is an equal level playing field. Furthermore Agbaje noted; "winning the digital payment race or dominating the market is beyond just acquiring the best of technology, because technology will become a commodity available to all...technology will never be the differentiator." By this assertion, Agbaje suggest that Fintech's only competitive edge - technology has a short life product cycle and not as lethal as it is generally thought to be. This paper agree with Agbaje, technology as we know them are hardly durable.

We agree with Abbasi and Weigand's (2017) argument, "digital financial services (DFS) expand the delivery of traditional banking services to the customers through innovative technologies like internet banking, mobilephone-enabled solutions, electronic money models and digital payment platforms." Our concern though remain the protection digitalization project could offer banks in the face of acrid competition from cost effective startup Fintech firms that effectively compete in traditional banking business financial services markets.

\subsection{Hypothesis}

Following arguments and the different strand of thoughts so far expressed in this paper, we hypothesis thus:

(i) The recent surge in conventional banking industry digitalization investments may not significantly improve banking sector profitability as it is expected.

(ii) Fintech firms though agile, cost effective, able to innovatively deploy technologies and structurally slim, may not, even in the long unforeseeable future, be able to out compete or obliterate conventional banks in the Nigeria Financial service markets space.

Dietz, Khanna, Olanrewaju, and Rajgopal (2016), noted: "Banking has historically been one of the business sectors most resistant to disruption by technology." "Banks have built robust businesses with multiple moats: ubiquitous distribution through branches; unique expertise such as credit underwriting underpinned by both data and judgment; even the special status of being regulated institutions that supply credit, the lifeblood of economic growth, and have sovereign insurance for their liabilities (deposits)." These overwhelming profiles of conventional banks make them almost unassailable, and not susceptible to some instant market competition from a sector with 
practically no history. Like the dot.com, Fintech could be an "ill wind" with a short life and blows nobody any good.

\subsection{Methodology}

We tested the two hypotheses stated in section 2.2 using selected banking sector bank key performance indicators (KPI). Because our data are mined from the annual reports of the selected banks, they do not qualify as time a series data by nature. We will analyze our hypothesis, using descriptive statistical tools such as: rate (percentages) of change, histogram, graphs and charts etc. We compare achievements (performance) of the four selected banks with highly digitalized functional units and services offering with the four others with less digitalized functional units, product and service offerings. The highly digitalized banks proxy fintech firms.

The less digitalized banks represent the normal banking firms. The result obtained will proxy the standings or resilience of banks versus Fintech startup firms in the competitive market. Has digitalization impacted banks' resilience, improved their competitive stamina so they are able to stand the steaming competition generated by Fintech firms' activities in the financial services market. If digitalization has been successful, how about the ever overcrowded and commotional banking halls across Nigeria?

The literature is brimful with several approaches to measuring bank performance including using key bank performance indicators (KPI). An anonymous source defined key performance indicator (KPI) for banks as: "a metric that can be successfully used to evaluate the success of a bank as a whole down to individual bank employees." From industry standard, financial performance metrics as Return on Assets (ROA) and Return on Equity (ROE), to more operationally focused metrics as accounts opened per employee and operating expenses as a percentage of assets as indicators are able to identify increase or shrink in a bank's profits. Digitalization is more of an operational enhanced tool for banks. This paper intends to establish a relationship between digitalization of banks and their performance in operational related areas: loan and advance to customers, customer deposits penetrations, personal expense and asset under management. We operationalize KPI that are enhanced by digitalization.

\subsection{Data Construction}

Four highly digitalized Nigeria banks proxy fintech start up firms: First Bank, Guaranty Trust (GTB), Zenith and Access Banks are randomly selected against: First City Monument (FCMB), Stanbic IBTC, Fidelity and Sterling banks less digitalized in operations and functional units that proxy normal banking firm. The status of either "highly or less digitalized" is not informed by any known objectively defined criteria. We designate a bank either as "highly or less digitalized" based on the frequency of her products and services (online) offering on the information technology high ways: google, networks, internet sport advertisement. A second criteria is the extent of digitalization of functional units, product and service offering. These products and services offering as key bank performance indicators (KPI) viz are chosen:

a) Customer deposits - the size of customer deposits earlier

explained variously in this paper is adopted to depict the benefits of liquidity of a bank. Customer deposits, though reported on banks' balance sheets as liabilities, are in reality an asset to a banks. Customer deposits provide needed liquidity banks use to dispense loan and advances to customers to earn interest spread which generate huge revenue to banks and contributes to it sustainability.

b) Loan and advances to customers - this tell us the benefits of

A banks earn by granting customer credit facilities. It is selected to report the additional benefits realized following digitalized function related to customer loan and advance dispensed using information technology traffic.

c) Asset under Management AUM). This is variously defined -

trading asset, financial assets held at fair value through profit or loss etc. Generally it refers to "how much money a hedge fund or financial institution is managing for their clients." Deployment of information technology, we believe, should quicken the acquisition of large asset to be managed. Also, value of asset under management (AUM) is a measure of the size of a financial institution and a key performance indicator of success. https://opsdog.com/resources/5-key-performance-indicators-for-banks-to-benchmark/

d) Banking operation expense - is a generic name, and it reports

different operating expenses ranging from "personal or staff cost", "administrative expense", and "other expenses." For this paper, we chose to operationalize "personal expense or staff cost." Accounting notes details for personal expense, unlike the other expenses, coalesced around similar items across banks. It thus provides a good basis for a rational analysis of bank operating expense. Staying competitive and resilient, a bank must regularly work to reduce it operational costs. To cut costs, and to simply survive, banks must transform their digital initiatives. Paul Krugman, a Nobel price economist, once said, "a company's financial health isn't just about money coming in: It's also about money going out." Has Bank digitalization projects reduced operational costs to keep bank operations cost competitive and increased money coming in?

Table 3.1 (A) and (B) below list the four key performance indicators (KPI) for banks covering 10 (ten) years 
period of data. Using conjecture, we selected eight: four banks we consider highly digitalized: - Access, First, Guaranty Trust and Zenith Banks; and four others considered to be less digitalized: - FCMB, Fidelity, Sterling and Stanbic IBTC Nigeria deposit money banks (MDB) to test the impact of the deployment of information technology. We compute percentage changes (negative or positive) in the selected key performance indicators (KPI) over a period of ten years for each bank and compare results to determine the impacts of technological deployment

\begin{tabular}{|c|c|c|c|c|c|c|c|c|c|}
\hline \multicolumn{5}{|c|}{$\begin{array}{l}\text { HIGHLY DIGITALIZED BANK } \\
2010\end{array}$} & \multicolumn{5}{|c|}{ LESS DIGITALIZED BANK } \\
\hline BANK & $\begin{array}{ll}\text { Asset } & \text { Under } \\
\text { Magt } & \\
\text { N } 000^{\prime}\end{array}$ & $\begin{array}{l}\text { Banking } \\
\text { Opt Expen } \\
\text { Nop0 }^{\prime} 000\end{array}$ & $\begin{array}{l}\text { Loan \& Adv. } \\
\text { to Customer } \\
\text { ₹y00 }\end{array}$ & $\begin{array}{l}\text { Customer } \\
\text { Deposits } \\
z^{\prime} 000\end{array}$ & BANK & $\begin{array}{ll}\text { Asset } & \text { Under } \\
\text { Magt } & \\
¥ 000 & \end{array}$ & $\begin{array}{l}\text { Banking } \\
\text { Opt Expen } \\
\text { N }^{\prime} 000\end{array}$ & $\begin{array}{l}\text { Loan \& Adv. } \\
\text { to Customer } \\
\text { N } 000 \text {. }\end{array}$ & $\begin{array}{l}\text { Customer } \\
\text { Deposits } \\
\mathbf{N}^{\prime} 000\end{array}$ \\
\hline Access Bank & $\mathbf{N} / \mathbf{A}$ & $38,797,403$ & $403,178,957$ & $440,542,115$ & FCMB & $71,916,099$ & $28,369,962$ & $323,531,060$ & $334,897,851$ \\
\hline First Bank Holding & 309,292 (M) & $107,392(\mathrm{M})$ & $1,046,925(\mathrm{M})$ & $1,330,771(\mathrm{M})$ & Fidelity Bank & $41,006(\mathrm{M})$ & $29,235(\mathrm{M})$ & $158,516(\mathrm{M})$ & $327,351(\mathrm{M})$ \\
\hline Guaranty Trust Bank & $148,872,254$ & $13,691,132$ & $563,383,562$ & $753,088,230$ & Sterling Bank & $96,593,620$ & $15,162,982$ & $99,312,070$ & $199,274,284$ \\
\hline Zenith Bank & 171,185 (M) & 89,074 (M) & $667,860(M)$ & $1,289,552(\mathrm{M})$ & Stanbic Bank & 37,689 (M) & 29,820 & $164,203(M)$ & 187,595 \\
\hline & & & & 2011 & & & & & \\
\hline Access Bank & $5,587,534$ & $38,964,674$ & $490,877,501$ & $522,599,292$ & FCMB & $3,010,135$ & $29,648,123$ & $315,101,376$ & $410,578,646$ \\
\hline First Bank Holding & 550,368 (M) & $134,786(\mathrm{M})$ & $1,128,851(\mathrm{M})$ & $1,784,490(\mathrm{M})$ & Fidelity Bank & $89,776(\mathrm{M})$ & $38,387(\mathrm{M})$ & $255,257(\mathrm{M})$ & $561,089(\mathrm{M})$ \\
\hline Guaranty Trust Bank & $173,297,556$ & $17,851,900$ & $679,358,919$ & $1,026,119,419$ & Sterling Bank & $194,785,083$ & $20,442,336$ & $159,734,616$ & $406,515,735$ \\
\hline Zenith Bank & $265,164(M)$ & $108,450(\mathrm{M})$ & 767,372(M) & $\begin{array}{l}1,575,977 \\
\text { (M) }\end{array}$ & Stanbic Bank & $60,530(\mathrm{M})$ & 36,029 & 230,707(M) & 295,905(m) \\
\hline & & & & 2012 & & & & & \\
\hline Access Bank & $3,769,260$ & $28,412,192$ & $554,592,199$ & $1,093,979,220$ & FCMB & 685,664 & $18,545,334$ & $357,798,798$ & $646,216,767$ \\
\hline First Bank Holding & $1,942(\mathrm{M})$ & $168,908(\mathrm{M})$ & $1,316,407(\mathrm{M})$ & $2,171,807(\mathrm{M})$ & Fidelity Bank & $241,663,451$ & $16,758,471$ & $350,489,990$ & $1,099,437$ \\
\hline Guaranty Trust Bank & $267,417,182$ & $18,468,570$ & $742,436,944$ & $1,054,122,573$ & Sterling Bank & $1,998,860$ & $9,392,577$ & $229,420,874$ & $463,726,325$ \\
\hline Zenith Bank & & & & $\begin{array}{l}1,802,008 \\
\text { (M) }\end{array}$ & Stanbic Bank & $114,877(\mathrm{M})$ & $21(\mathrm{M})$ & $266,344(\mathrm{M})$ & 355,419 (M) \\
\hline & & & & 2013 & & & & & \\
\hline Access Bank & $3,877,969$ & $25,937,818$ & $735,300,74$ & $1,217,176,793$ & FCMB & $2,921,358$ & 70,379 & $450,532,965$ & $715,214,192$ \\
\hline First Bank Holding & $2,225(M)$ & $159,119(\mathrm{M})$ & $1,473,893(\mathrm{M})$ & $\begin{array}{l}2,570,719 \\
\text { (M) }\end{array}$ & Fidelity Bank & $254,909(\mathrm{M})$ & $25,629(\mathrm{M})$ & $426,076(\mathrm{M})$ & $806,320(\mathrm{M})$ \\
\hline Guaranty Trust Bank & $13,746,682$ & $19,625,269$ & $926,967,093$ & $1,261,927,035$ & Sterling Bank & $2,200,994$ & $10,266,263$ & $321,743,748$ & $570,511,097$ \\
\hline Zenith Bank & & $27066(M)$ & $1,126,559$ (M) & $2,079,262(\mathrm{M})$ & Stanbic Bank & $40,71(\mathrm{M})$ & $456(\mathrm{M})$ & $289,747(\mathrm{M})$ & $416,352(\mathrm{M})$ \\
\hline & & & & 2014 & & & & & \\
\hline Access Bank & N/A & $25,611,051$ & $1,019,908,848$ & $1,324,800,611$ & FCMB & 741,917 & 306,667 & $617,979,790$ & $733,796,796$ \\
\hline First Bank Holding & $9,258(M)$ & $63,011(\mathrm{M})$ & $1,794,037(\mathrm{M})$ & $\begin{array}{l}2,551,015 \\
\text { (M) }\end{array}$ & Fidelity Bank & $83,363(\mathrm{M})$ & $25,874(\mathrm{M})$ & $541,686(\mathrm{M})$ & $820,034(\mathrm{M})$ \\
\hline Guaranty Trust Bank & $5,675,545$ & $21,036,543$ & $1,182,393,874$ & $1,439,522,070$ & St & 1,94 & $12,031,026$ & $371,246,273$ & $655,944,127$ \\
\hline Zenith Bank & & $67,848(\mathrm{M})$ & $1,580,250(\mathrm{M})$ & $2,265,262(M)$ & Stanbic Bank & $96,345(M)$ & $455(\mathrm{M})$ & 398,604(M) & 494,935(M) \\
\hline
\end{tabular}

Table 3.1: (A) Bank Key Performance Indicator (KPI): Highly Digitalized v. Less Digitalized Bank Source: Generated by the Authors from Banks' (2010 - 2019) Annual Reports

\begin{tabular}{|c|c|c|c|c|c|c|c|c|c|}
\hline \multicolumn{5}{|c|}{$\begin{array}{l}\text { HIGHLY DIGITALIZED BANK } \\
2015\end{array}$} & \multicolumn{5}{|c|}{$\begin{array}{l}\text { LESS DIGITALIZED BANK } \\
2015\end{array}$} \\
\hline BANK & $\begin{array}{l}\text { Asset } \\
\text { Magd } \\
\text { Magd } \\
\text { Noy0 }^{\prime} 00\end{array}$ & $\begin{array}{c}\text { Banking } \\
\text { Opt. Cost } \\
\text { ₹'000 }\end{array}$ & $\begin{array}{l}\text { Loan \& Adv. } \\
\text { to Customer } \\
¥ 000\end{array}$ & $\begin{array}{l}\text { Customer } \\
\text { Deposits } \\
\AA^{\prime} 000\end{array}$ & BANK & $\begin{array}{l}\text { Asset Under } \\
\text { Magt } \\
\approx^{\prime} 000\end{array}$ & $\begin{array}{l}\text { Banking } \\
\text { Opt. Cost } \\
\aleph^{\prime} 000\end{array}$ & 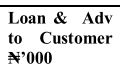 & $\begin{array}{l}\text { Customer } \\
\text { Deposits } \sharp^{\prime} 000\end{array}$ \\
\hline Access Bank & $10,403,608$ & $35,699,471$ & $1,243,215,309$ & $1,528,213,883$ & FCMB & $1,994,350$ & 238,360 & $592,957,417$ & $700,216,706$ \\
\hline First Bank Holding & $5,049(\mathrm{M})$ & 63,672(M) & $1,457,285$ (M) & $\begin{array}{l}3,104,221 \\
\text { (M) }\end{array}$ & Fidelity Bank & $4,070(\mathrm{M})$ & $27,125(\mathrm{M})$ & $578,203(\mathrm{M})$ & $769,636(\mathrm{M})$ \\
\hline Guaranty Trust Bank & $25,075,618$ & $\begin{array}{l}20,727,835 \\
\end{array}$ & $1,265,207,443$ & $1,422,550,125$ & Sterling Bank & $4,692,636$ & $12,101,326$ & $\begin{array}{l}338,726,271 \\
\end{array}$ & $5990,889,216$ \\
\hline Zenith Bank & $150,724(\mathrm{M})$ & $62,235(\mathrm{M})$ & $1,849,225(\mathrm{M})$ & $2,333,017(\mathrm{M})$ & Stanbic Bank & 37,956 (M) & $429 \mathrm{M}$ & $353,513(M)$ & 493,513(M \\
\hline & & & 2016 & & & & & & \\
\hline Access Bank & $14,871,247$ & $42,155,587$ & $1,594,562,345$ & $1,813,042,872$ & FCMB & $9,154,198$ & 218,167 & $659,937,237$ & $657,609,807$ \\
\hline First Bank Holding & $23,482(\mathrm{M})$ & 702(M) & $65(M)$ & $\begin{array}{l}3,104,221 \\
\text { (M) }\end{array}$ & Fidelity Bank & $18,098(\mathrm{M})$ & $27,231(\mathrm{M})$ & $718,401(\mathrm{M})$ & 792,971(M) \\
\hline Guaranty Trust Bank & $6,321,370$ & $20,704,772$ & $1,417,217,952$ & $1,681,184,820$ & Sterling Bank & $1,652,863$ & $11,521,854$ & $468,249,870$ & $584,733,896$ \\
\hline Zenith Bank & $118,622(\mathrm{M})$ & $62,428(\mathrm{M})$ & $2,138,132(\mathrm{M})$ & $2,556,963(\mathrm{M})$ & Stanbic Bank & $16,855(\mathrm{M})$ & $500(\mathrm{~m})$ & $352,965(\mathrm{M})$ & $560,969(\mathrm{M})$ \\
\hline & & & & 2017 & & & & & \\
\hline Access Bank & $20,257,131$ & $41,773,512$ & $1,771,282,739$ & $1,910,773,713$ & FCMB & $23,936,031$ & 265,056 & $649,796,726$ & $689,860,640$ \\
\hline First Bank Holding & $83,713(\mathrm{M})$ & 982 (Mil) & 108 (Mil) & $3,143,338$ & Fidelity Bank & $20,639(\mathrm{M})$ & $24,535(\mathrm{M})$ & $768,737(\mathrm{M})$ & $775,276(\mathrm{M})$ \\
\hline Guaranty Trust Bank & $16,652,356$ & $22,354,351$ & $1,265,971,688$ & $1,697,560,947$ & Sterling Bank & $6,883(M)$ & $11,545(\mathrm{M})$ & $598,073(M)$ & $684,834(\mathrm{M})$ \\
\hline Zenith Bank & $117,814(\mathrm{M})$ & $55,672(\mathrm{M})$ & $1,980,464(\mathrm{M})$ & $2,744,525(\mathrm{M})$ & Stanbic Bank & $151,479 \mathbf{M}$ & $590 \mathrm{M}$ & $372,088(\mathrm{M})$ & $753,642(\mathrm{M})$ \\
\hline & & & & 2018 & & & & & \\
\hline Access Bank & $23,839,394$ & $40,425,816$ & $1,681,761,862$ & $2,058,738,930$ & FCMB & $47,426,813$ & $19,727,544$ & $569,900,550$ & 802,853211 \\
\hline First Bank Holding & 3,427 (Mil) & 904 (Mil) & $110(\mathrm{M})$ & $3,486,691(\mathrm{M})$ & Fidelity Bank & $14,052(\mathrm{M})$ & $23,910(M)$ & 849,880 (M) & 979,413 (M) \\
\hline Guaranty Trust Bank & $8,920,153$ & $23,681,401$ & $1,067,999,019$ & $1,865,816,172$ & Sterling Bank & $4,110(M)$ & $13,194(\mathrm{M})$ & 621,017 (M) & $760,604(\mathrm{M})$ \\
\hline Zenith Bank & $156,673(\mathrm{M})$ & $56,657(\mathrm{M})$ & $1,736,066(\mathrm{M})$ & $2,821,066(M)$ & Stanbic Bank & $84,351(\mathrm{M})$ & $1,662(\mathrm{M})$ & $441,261(\mathrm{M})$ & $807,692(\mathrm{M})$ \\
\hline & & & & 2019 & & & & & \\
\hline Access Bank & $28,291,959$ & $60,712,847$ & $2,481,623,671$ & $3,668,339,81$ & FCMB & $50,923,740$ & $22,228,216$ & $649,663,453$ & $918,301,254$ \\
\hline First Bank Holding & 3,057 (Mil) & $1,201(\mathrm{M})$ & $94(\mathrm{M})$ & $4,019,836 \mathrm{M}$ & Fidelity Bank & $45,538(\mathrm{M})$ & $24,129(\mathrm{M})$ & $1,126,974(\mathrm{M})$ & $1,225,213(\mathrm{M})$ \\
\hline Guaranty Trust Bank & $44,717,688$ & $23,330,656$ & $1,300,820,647$ & $2,086,810,070$ & Sterling & $8,317(\mathrm{M})$ & $14,912(\mathrm{M})$ & $618,732(\mathrm{M})$ & $60(\mathrm{M})$ \\
\hline Zenith Bank & $189,358(\mathrm{M})$ & $62,038(\mathrm{M})$ & $2,239,472(\mathrm{M})$ & $3,486,887(\mathrm{M})$ & Stanbic Bank & 248,909 (M) & 1,056 (M) & $535,170(\mathrm{M})$ & $637,840(\mathrm{M})$ \\
\hline
\end{tabular}

Table 3.1 (B) Bank Key Performance Indicators (KPI): Highly digitalized v Less digitalized Bank. Source: Generated by the Authors from Banks' (2010 - 2019) Annual Reports.

\subsection{Analysis of data and discussion of findings}

The data presented in Tables 4.1 (A) and (B) are further processed (see Tables 3.2 (a) (b) (c) and (d)) to compare percentage changes relation between the four banks' key performance index (KPI) across the four highly digitalized and the less digitalized banks via:

- Customer deposit,

- Loan and Advances to customers

- Asset Under management

- Bank operation expense

Table 4.2 presents the rate of (\%) changes in customer deposits in a highly digitalized (Access Bank) with a less digitalized Stanbic ibtc bank. Fig 4.1 presents in graphical form the relationship between the rate (\%) changes in the index in either bank. From the graph in Fig. 4.1, we observed no real significant difference between customer deposits in highly digitalized Access bank and the less digitalized Stanbic ibtc bank. We noticed though, between 
2013 through 2014, customers deposits in Access Bank dipped negatively, Stanbic ibtc bank, a less digitalized bank stayed positively and above zero.

\section{Table 4.2 Rate of Change (\%) \\ Customer Deposits}

\section{Rate of}

change $(\%)$ :

\pm Customer

Deposits:

Acess Bank

2010

2011

2012

2013

2014

2015

2016

2017

2018

2019
Rate of

change (\%)

\pm Customer

Deposits:

Stanbic Bank

20.11253612

$\begin{array}{rr}52.2294705 & 17.14399061 \\ 10.12158412 & 18.87417378\end{array}$

$-19.3417230 \quad-0.28731045$

$33.26138053 \quad 13.66853558$

$4.160919904 \quad 34.34646121$

$9.976972626 \quad 7.171840211$

$-5.32304121-21.0293032$

$32.23139021 \quad-100$
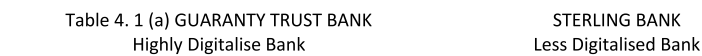

Loan \& Adv. to

Customers $A$

000

$563,383,562$

$679,358,919$

$742,436,944$

$926,967,093$

$1,182,393,874$

$1,265,207,443$

$1,417,217,952$

$1,265,971,688$

$1,067,999,019$

$1,300,820,647$
Table 4.1 (b) ACCESS BANK

Highly Digitalise Bank
STANBIC BANK Less Digitalised Bank

Table 4. 3 Rate of change

(\%) Loan \& Advances to

\section{Customers}

$\begin{array}{ccc} & \begin{array}{c}\text { \% change } \\ \pm \text { Loan \& } \\ \text { Adv. GT } \\ \text { Bank }\end{array} & \begin{array}{c}\text { \% change } \\ \text { Adv. Loan \& } \\ \text { Bank }\end{array} \\ \text { Year } & \text { Bank } \\ 2010 & & \\ 2011 & 17.0712938 & 37.82683273 \\ 2012 & 8.49607842 & 30.37485508 \\ 2013 & 19.9068716 & 28.6945355 \\ 2014 & 21.6025122 & 13.33414733 \\ 2015 & 6.54545383 & -9.60067311 \\ 2016 & 10.7259796 & 27.66121409 \\ 2017 & -11.947049 & 21.70690367 \\ 2018 & -18.536784 & 3.69458485 \\ 2019 & 17.8980575 & -0.36930367\end{array}$

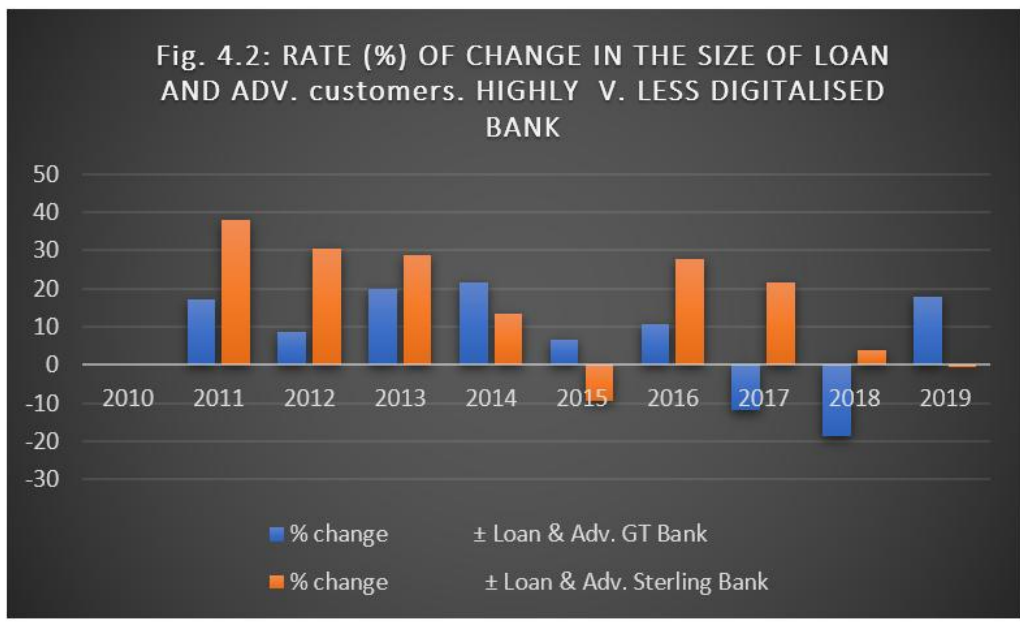

$\begin{array}{llll}\text { Source: } & \text { Generated } & \text { from } & \text { Table }\end{array}$

We analyzed, using the same rate (\%) of change, in the size of loan and advances to customers in a highly digitalized Guaranty Trust bank and compared the result with the rate (\%) of change in a less digitalized Sterling Bank. We tested for the disparity, in favour of Guaranty Trust Bank for a larger rate (\%) of change in the size of loan and advances to customers as against a smaller volume of change in loan and advance in Sterling, a less digitalized bank. Our findings shown in the histogram in Fig. 4.2 generated from Table 4.3 is a paradox. Sterling bank, against our earlier conjecture, in all the years, except 2017 and 2018, granted higher level of loans and 
advances to customers than Guaranty Trust Bank a highly digitalized bank.

Similarly, we examined the (\%) rate of change in the value of asset under management between First Bank Holdings a highly digitalized bank, compare to a less digitalized First City Monument Bank (FCMB). The (\%) rate of change in the value of asset under management between these banks is represented on the Table 4.4 and further illustrated with the histogram in Figure 4.3 below. Our findings revealed a less digitalized First City Monument Bank (FCMB) having higher percentage rate of change of asset under management than a highly digitalized First Bank Holdings in all the years except, 2018 and partially 2019 when First Bank Holding is negative.

Table 4.4 Rate of change (\%) Asset under Management

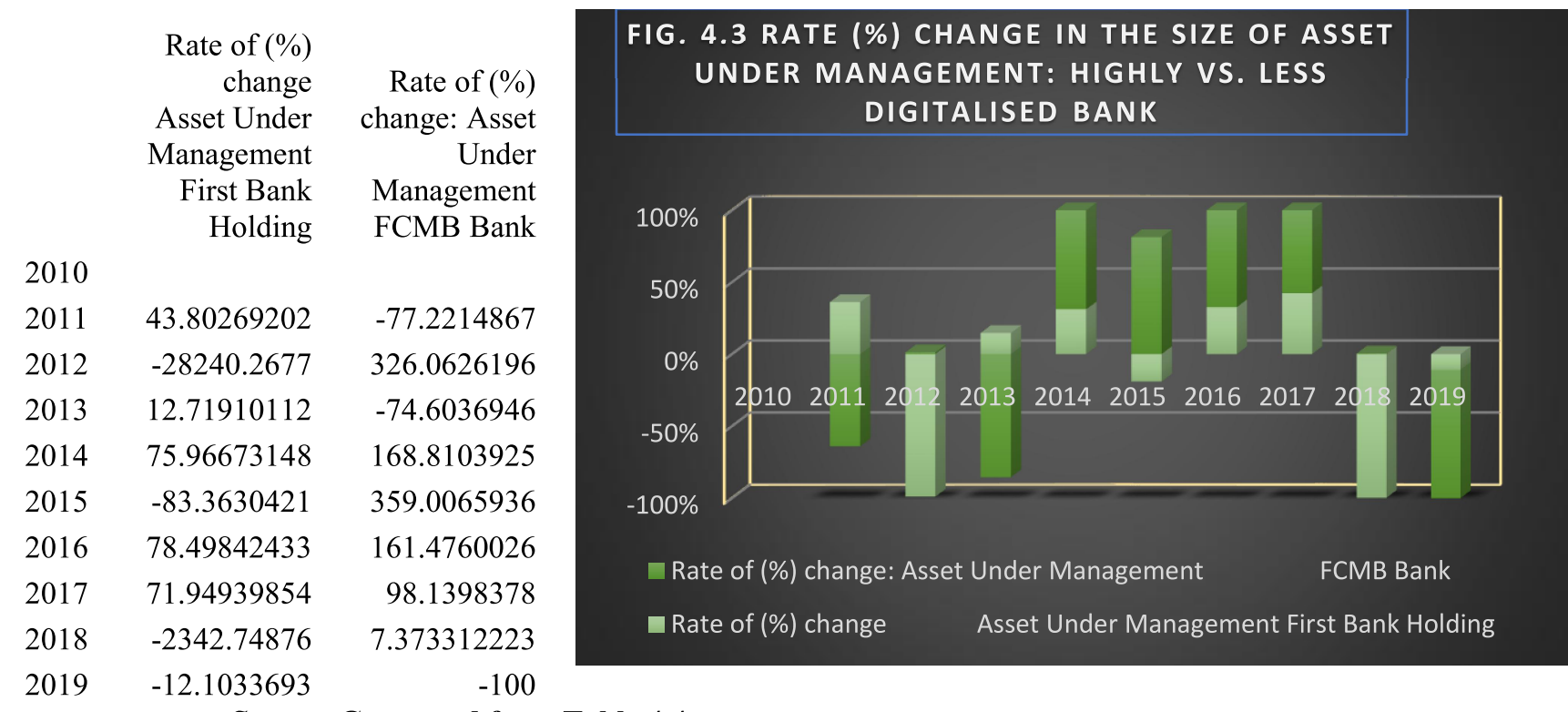

Source: Generated form Table 4.4

\subsection{Discussion of findings}

In all three cases analyzed, the less digitalized banks representing normal banking firms outperformed the highly digitalized banks - the Fintech startup firms group. These findings support the two hypothesis stated in section 2.2 and proposed for this work. By these findings, we are of the opinion, the recent surge in digitalization in banking functions, services and product offerings are a vain effort, waste, and an unnecessary destruction of shareholder value. It added nothing significant to improving banking sector profitability as it was falsely propagated in banks' annual general meetings (AGM) and board rooms.

Moreover, our finding supports opinion in extant literature (Agboola, M.G et al 2014, Dietz, et al. 2016). Fintech startup firms are not able to out compete Nigeria deposit money banks neither in the Nigeria Financial service markets space nor in any other financial related market sectors. Fintech startup are no threat to the brickand-mortar model. Banking is not about technological deployment which only enhance service and product offerings on the short run and little more thereafter. We are unable, though to outrightly deny the value chain additions due technological deployment: ATM, payment gateway, transfers etc. their contribution are only marginal. Despite ATM banking hall are still overcrowded said one Bank.

That our hypothesis is proven right is one thing. The disturbing issue though at discussion is to explain why the less digitalized banks outperformed the highly celebrated digitalized banks - the Fintech startups. One possible explanation could be that technological deployments in banking service offerings and functional units, except the payment gateway: (ATM, transfers and perhaps few others) does little or nothing improving cash flow to banks. The high incidence of technological deployment in commercial banking services, benefits the payment gateway where Fintech startup are also active due mainly to the financial exclusion prevalently experienced in many subSahara African countries including Nigeria (see Appendix A for further details) but not revenue generation. Gateway payment cash flow receipts are tokens when compared to interest spread on loan and advance. It thus contributes marginally in revenue generation to banks.

It is also doubtful the extent of the contribution of information technology to banking services offerings. One banker once asked, "why is that banking halls are still overcrowded if technological deployment is of benefit." 


\section{Recommendation and conclusion}

As McKinsey \& Company (December 2020) in its recent Global Banking Annual Review, noted, to stay competitive, banks should reduce its cost-to-income ratio and not add on functions. It should improve its "productivity engine", that is, improve its capital management capabilities and re-build its risk-management muscles to stymie competition. From indications, Nigeria deposit money banks (DMB) may not sufficiently achieve cost savings enough to ward off the competition from Fintech startup firms only in a massive one off digital implementations programs. Rather, a mindset and capabilities: - reset third party spending, move to minimum viable central functions and dedicated to continuous improvement aimed at greater productivity and better customer experience could generate the needed resilience for deposit money banks (DMB) to stay competitive in the new global financial market.

\section{Reference}

https://www.consultancy.eu/news/2390/global-fintech-investment-more-than-Doubled-to-112-billion

Abbasi, T. and Weigand, H. (2017. The Impact of Digital Financial Services on Firm's Performance: a Literature Review. Quantities Finance Cornell University Access Bank (2010 - 2019). Annual Report and Accounts

Agboola, M.G et al (2014). Effect of digitalization on the performance of commercial banks in Nigeria. IOP Conf. Ser.: Earth Environ. Sci. 331012014 doi:10.1088/1755- 1315/331/1/012014.

BCBS (2017). Sound Practices: Implications of Fintech developments for banks and bank supervisors

Dietz, et al. (2016). Cutting through the noise around financial technology. McKinsey \& Company.

Fidelity Bank Nig. Plc. (2010 - 2019) Annual Report and Accounts

First Bank Nig. Plc. (2010 - 2019) Annual Report and Accounts

First City Monument Bank (FCMB) Nig. Plc. (2010 - 2019) Annual Report and Account

Graham, A. (undated). Fintech and Banks: How can the banking industry respond to the threat of disruption? Moneta International UAB)

Gregson, J. (2019). Africa's Fintech makeover. The Magazine.

Guaranty Trust Bank Nig. Plc. $(2010$ - 2019) Annual Report and Accounts

Hientz, L. \& Bhatia, C. (2019) Fintechs in Sub-Saharan Africa: an overview of market Developments and investment opportunities. EYGM 1td. No. 012051-18GbI

Kagan, J. (2020). Financial Technology - Fintech. Investopedia

Kola-Oyeneyin, E. Kuyro, M. Olarewuju T. al. (2020).Harnessing Nigeria's Fintech potential Financial Services McKinsey and Company.

PwC (undated). Changing competitive land scape in Nigeria. Fintech and the Banking sector in Nigeria.

McKinsey \& Company (2020). A test of resilience: Banking through the crises and beyond McKinsey Global Banking Annual Review.

Samuel, J. (2020). VC investment in Fintech remains robust as M\&A activity Stalls: KPMG Pulse of Fintech. KPMG International.

Stanbic ibtc Bank Nig. Plc. (2010 - 2019) Annual Report and Accounts

Sterling Bank Nig. Plc. $(2010$ - 2019) Annual Report and Accounts

Timm, S. (2019): 10 ways Africa's Fintech sector boomed in 2019 - Ventureburn https://ventureburn.com/2019/12/10-ways-africas.

Yermack, D. (2018). Fintech in sub-Saharan Africa: what has worked well, and what Hasn't. Working Paper 25007 http://www.nber.org/papers/w25007 National Bureau Of Economic Research (NBER) 1050 Massachusetts Avenue Cambridge, MA 02138.

Zenith Bank Nig. Plc. (2010 - 2019) Annual Report and Accounts 


\section{Appendix A}

\section{Table 1}

\section{FinTech infrastructure}

\begin{tabular}{|c|c|c|c|c|c|}
\hline Nation & Legal heritage & $\begin{array}{l}\text { Electrical } \\
\text { penetration }\end{array}$ & $\begin{array}{c}\text { Internet } \\
\text { penetration }\end{array}$ & $\begin{array}{l}\text { Mobile phone } \\
\text { penetration }\end{array}$ & $\begin{array}{l}\text { Days to start } \\
\text { a new business }\end{array}$ \\
\hline Benin & Civil law & $32 \%$ & $33.1 \%$ & $88.1 \%$ & 9 \\
\hline Burkina Faso & Civil law & $20 \%$ & $18.8 \%$ & $79.8 \%$ & 13 \\
\hline Cameroon & Civil law & $63 \%$ & $24.8 \%$ & $79.5 \%$ & 17 \\
\hline Central African Rep. & Civil law & $3 \%$ & $5.4 \%$ & $27.3 \%$ & 22 \\
\hline Chad & Civil law & $9 \%$ & $5.0 \%$ & $39.0 \%$ & 60 \\
\hline Congo, Democ. Rep. & Civil law & $15 \%$ & $6.1 \%$ & $49.5 \%$ & 7 \\
\hline Congo, Rep. of & Civil law & $43 \%$ & $12.0 \%$ & $104.4 \%$ & 49 \\
\hline Côte d'Ivoire & Civil law & $62 \%$ & $26.3 \%$ & $109.9 \%$ & 7 \\
\hline Ethiopia & Civil law & $45 \%$ & $15.3 \%$ & $42.4 \%$ & 33 \\
\hline Gabon & Civil law & $90 \%$ & $47.7 \%$ & $146.2 \%$ & 33 \\
\hline Guinea & Civil law & $20 \%$ & $12.3 \%$ & $89.5 \%$ & 8 \\
\hline Madagascar & Civil law & $23 \%$ & $7.2 \%$ & $44.1 \%$ & 8 \\
\hline Mali & Civil law & $41 \%$ & $65.3 \%$ & $129.9 \%$ & 9 \\
\hline Mauritania & Civil law & $31 \%$ & $17.8 \%$ & $87.5 \%$ & 6 \\
\hline Mozambique & Civil law & $29 \%$ & $17.3 \%$ & $71.9 \%$ & 19 \\
\hline Niger & Civil law & $11 \%$ & $4.3 \%$ & $45.0 \%$ & 7 \\
\hline Rwanda & Civil law & $30 \%$ & $29,8 \%$ & $75.3 \%$ & 4 \\
\hline Senegal & Civil law & $64 \%$ & $59.8 \%$ & $99.9 \%$ & 6 \\
\hline South Sudan & Civil law & $1 \%$ & $17.3 \%$ & $24.4 \%$ & 13 \\
\hline Togo & Civil law & $35 \%$ & $11.3 \%$ & $65.5 \%$ & 6 \\
\hline Botswana & Common law & $55 \%$ & $39.6 \%$ & $157.3 \%$ & 48 \\
\hline Ghana & Common law & $84 \%$ & $34.3 \%$ & $126.9 \%$ & 14 \\
\hline Kenya & Common law & $65 \%$ & $85.0 \%$ & $79.8 \%$ & 25 \\
\hline Lesotho & Common law & $34 \%$ & $27.7 \%$ & $98.4 \%$ & 29 \\
\hline Liberia & Common law & $12 \%$ & $8.1 \%$ & $81.2 \%$ & 5 \\
\hline Malawi & Common law & $11 \%$ & $9.5 \%$ & $37.4 \%$ & 37 \\
\hline Mauritius & Common law & $100 \%$ & $63.4 \%$ & $139.9 \%$ & 6 \\
\hline Namibia & Common law & $56 \%$ & $30.8 \%$ & $105.1 \%$ & 66 \\
\hline Nigeria & Common law & $61 \%$ & $50.2 \%$ & $83.2 \%$ & 19 \\
\hline Sierra Leone & Common law & $9 \%$ & $11.7 \%$ & $78.2 \%$ & 11 \\
\hline South Africa & Common law & $86 \%$ & $53.7 \%$ & $159.2 \%$ & 45 \\
\hline Tanzania & Common law & $33 \%$ & $38.9 \%$ & $73.6 \%$ & 28 \\
\hline Uganda & Common law & $19 \%$ & $42.9 \%$ & $50.4 \%$ & 24 \\
\hline Zambia & Common law & $34 \%$ & $41.2 \%$ & $71.8 \%$ & 9 \\
\hline Zimbabwe & Common law & $34 \%$ & $40.2 \%$ & $80.9 \%$ & 61 \\
\hline 9 Means & Civil law & $33.4 \%$ & $21.8 \%$ & $75.0 \%$ & 17 \\
\hline & Common law & $46.2 \%$ & $38.5 \%$ & $94.9 \%$ & 28 \\
\hline$p$-value difference in & means .15 & .01 & & .10 & -.6 \\
\hline
\end{tabular}


iii

Appendix B

\begin{tabular}{|c|c|c|c|c|c|c|c|c|c|c|c|c|}
\hline \multirow[b]{2}{*}{ Year } & \multicolumn{3}{|c|}{$\begin{array}{l}\text { GUARANTY TRUST BANK } \\
\text { Highly Digitalise Bank }\end{array}$} & \multicolumn{3}{|c|}{$\begin{array}{c}\text { STERLING BANK } \\
\text { Less Digitalised Bank }\end{array}$} & \multicolumn{3}{|c|}{$\begin{array}{c}\text { ACCESS BANK } \\
\text { Highly Digitalise Bank }\end{array}$} & \multicolumn{3}{|c|}{$\begin{array}{c}\text { STANBIC BANK } \\
\text { Less Digitalised Bank }\end{array}$} \\
\hline & $\begin{array}{l}\text { Loan \& Adv. } \\
\text { to Customers } \\
A^{\prime} 000\end{array}$ & Changes & $\begin{array}{c}\% \text { change } \\
\pm\end{array}$ & $\begin{array}{l}\text { Advances to } \\
\text { customers } \\
\text { '000 }\end{array}$ & Changes & $\begin{array}{c}\% \text { change } \\
\pm\end{array}$ & $\begin{array}{c}\text { CUSTOMER } \\
\text { DEPOSIT } \\
\text { A'000 }\end{array}$ & Changes & $\begin{array}{c}\text { \% change } \\
\pm\end{array}$ & $\begin{array}{c}\text { CUSTOMER } \\
\text { DEPOSIT } \\
\text { N'OOO }^{\prime} 0\end{array}$ & Changes & $\begin{array}{c}\% \text { change } \\
\pm\end{array}$ \\
\hline 2010 & $563,383,562$ & $115,975,357$ & & $99,312,070$ & & & 440,542 & 82,057 & & 187,595 & 108,310 & \\
\hline 2011 & $679,358,919$ & $63,078,025$ & 17.0712938 & $159,734,616$ & $60,422,546$ & 37.826833 & 522,599 & 571,380 & 15.701739 & 295,905 & 59,514 & 20.1125361 \\
\hline 2012 & $742,436,944$ & $184,530,149$ & 8.49607842 & $229,420,874$ & $69,686,258$ & 30.374855 & $1,093,979$ & 123,198 & 52.229505 & 355,419 & 60,933 & 17.1439906 \\
\hline 2013 & $926,967,093$ & $255,426,781$ & 19.9068716 & $321,743,748$ & $92,322,874$ & 28.694536 & $1,217,177$ & $-1,084,696$ & 10.121584 & 416,352 & 78,583 & 18.8741738 \\
\hline 2014 & $1,182,393,874$ & $82,813,569$ & 21.6025122 & $371,246,273$ & $49,502,525$ & 13.334147 & 132,481 & $1,395,733$ & -818.75844 & 494,935 & $-1,422$ & -0.28731045 \\
\hline 2015 & $1,265,207,443$ & $152,010,509$ & 6.54545383 & $338,726,271$ & $-32,520,002$ & -9.600673 & $1,528,214$ & 284,829 & 91.331016 & 493,513 & 67,456 & 13.6685356 \\
\hline 2016 & $1,417,217,952$ & $-151,246,264$ & 10.7259796 & $468,249,870$ & $129,523,599$ & 27.661214 & $1,813,043$ & 97,731 & 15.709997 & 560,969 & 192,673 & 34.3464612 \\
\hline 2017 & $1,265,971,688$ & $-197,972,669$ & -11.947049 & $598,073,000$ & $129,823,130$ & 21.706904 & $1,910,774$ & 147,965 & 5.1147261 & 1753,642 & 54,050 & 7.17184021 \\
\hline 2018 & $1,067,999,019$ & $232,821,628$ & -18.536784 & $621,017,000$ & $22,944,000$ & 3.6945849 & $2,058,739$ & $1,609,601$ & 7.1871773 & 807,692 & $-169,852$ & -21.0293032 \\
\hline 2019 & $1,300,820,647$ & $-1,300,820,647$ & 17.8980575 & $618,732,000$ & $-2,285,000$ & -0.369304 & $3,668,340$ & $-3,668,340$ & 43.878184 & 637,840 & $-637,840$ & $-10 r$ \\
\hline ,0Ia & I'300'850'eds & $-J^{\prime} 300^{\prime} 850^{\prime} \mathrm{eds}$ & $\mathrm{T} 182802 \pm 2$ & eт8' $135^{\prime} 000$ & $-5 ' 582^{\prime} 000$ & -0 зеазо⿱ & $3^{\prime}$ 'ee8'3ง0 & $-3^{\prime} е e 8^{\prime} 3 \pm 0$ & t3'81818t & e3s'8v0 & $-e 3 s^{\prime} 8 \pm 0$ & $-\mathrm{TOC}$ \\
\hline 5018 & T'0es'aаa'01а & $535{ }^{\prime} 85 T^{\prime} e 58$ & $-1823 e 184$ & estors'o0o & $55 s^{\prime} \partial t^{\prime} 000$ & 3.eave8va & $5^{4} 028^{\prime} \pm 3 \partial$ & J'eoa'eot & ม'78دJม13 & 801'eas & -теа'825 & -5T05a3035 \\
\hline & J'se2 ast es:8 & - ras'aus'eea & $-1172450 t a$ & & & & T'aro'but & Itsiaez & 2'muser & & 281020 & \\
\hline & & & & & & & & & & & & \\
\hline
\end{tabular}

